\title{
Stem cell therapies for periodontal tissue regeneration: a network meta-analysis of preclinical studies
}

Qiang $\mathrm{Li}^{1,2+}$, Guangwen Yang ${ }^{1,2+}$, Jialing $\mathrm{Li}^{2,3}$, Meng Ding ${ }^{2}$, Na Zhou ${ }^{1}$, Heng Dong ${ }^{1,2^{*}}$ (I) and Yongbin Mou ${ }^{1^{*}}$

\begin{abstract}
Background: Periodontal tissue regeneration (PTR) is the ultimate goal of periodontal therapy. Currently, stem cell therapy is considered a promising strategy for achieving PTR. However, there is still no conclusive comparison that distinguishes clear hierarchies among different kinds of stem cells.

Methods: A systematic review and network meta-analysis (NMA) was performed using MEDLINE (via PubMed), EMBASE, and Web of Science up to February 2020. Preclinical studies assessing five types of stem cells for PTR were included; the five types of stem cells included periodontal ligament-derived stem cells (PDLSCs), bone marrowderived stem cells (BMSCs), adipose tissue-derived stem cells (ADSCs), dental pulp-derived stem cells (DPSCs), and gingival-derived stem cells (GMSCs). The primary outcomes were three histological indicators with continuous variables: newly formed alveolar bone (NB), newly formed cementum (NC), and newly formed periodontal ligament (NPDL). We performed pairwise meta-analyses using a random-effects model and then performed a random-effects NMA using a multivariate meta-analysis model.
\end{abstract}

Results: Sixty preclinical studies assessing five different stem cell-based therapies were identified. The NMA showed that in terms of NB, PDLSCs (standardized mean difference 1.87, 95\% credible interval 1.24 to 2.51), BMSCs (1.88, 1.17 to 2.59$)$, and DPSCs $(1.69,0.64$ to 2.75$)$ were statistically more efficacious than cell carriers (CCs). In addition, PDLSCs were superior to GMSCs (1.49, 0.04 to 2.94). For NC, PDLSCs (2.18, 1.48 to 2.87), BMSCs (2.11, 1.28 to 2.94), and $\operatorname{ADSCs}(1.55,0.18$ to 2.91) were superior to CCs. For NPDL, PDLSCs (1.69, 0.92 to 2.47$)$ and BMSCs (1.41, 0.56 to 2.26) were more efficacious than CCs, and PDLSCs $(1.26,0.11$ to 2.42) were superior to GMSCs. The results of treatment hierarchies also demonstrated that the two highest-ranked interventions were PDLSCs and BMSCs.

Conclusion: PDLSCs and BMSCs were the most effective and well-documented stem cells for PTR among the five kinds of stem cells evaluated in this study, and there was no statistical significance between them. To translate the stem cell therapies for PTR successfully in the clinic, future studies should utilize robust experimental designs and reports.

Keywords: Stem cell therapy, Periodontitis, Periodontal defects, Periodontal tissue regeneration, Tissue engineering, Network meta-analysis

\footnotetext{
* Correspondence: dongheng90@smail.nju.edu.cn; yongbinmou@163.com

${ }^{\dagger}$ Qiang Li and Guangwen Yang contributed equally to this work.

'Department of Oral Implantology, Nanjing Stomatological Hospital, Medical School of Nanjing University, Nanjing, China

Full list of author information is available at the end of the article
}

(c) The Author(s). 2020 Open Access This article is licensed under a Creative Commons Attribution 4.0 International License, which permits use, sharing, adaptation, distribution and reproduction in any medium or format, as long as you give appropriate credit to the original author(s) and the source, provide a link to the Creative Commons licence, and indicate if changes were made. The images or other third party material in this article are included in the article's Creative Commons licence, unless indicated otherwise in a credit line to the material. If material is not included in the article's Creative Commons licence and your intended use is not permitted by statutory regulation or exceeds the permitted use, you will need to obtain permission directly from the copyright holder. To view a copy of this licence, visit http://creativecommons.org/licenses/by/4.0/ The Creative Commons Public Domain Dedication waiver (http://creativecommons.org/publicdomain/zero/1.0/) applies to the data made available in this article, unless otherwise stated in a credit line to the data. 


\section{Introduction}

Periodontitis is a chronic bacteriological disease characterized by a series of tooth-supporting structures (gingiva, periodontal ligament, cementum, and alveolar bone) in a state of inflammation, resulting in progressive damage, such as gingival atrophy, alveolar bone resorption, and tooth loss [1]. Currently, the overall prevalence of periodontitis is as high as 45 to $50 \%$, making it the sixth most common human disease and a substantial public health burden worldwide [2]. Periodontitis is also considered to be associated with the occurrence and prognosis of many systemic diseases [3]. Therefore, effective and safe periodontal therapy methods are urgently needed.

The ultimate goal of periodontal therapy is to inhibit periodontitis progression and promote periodontal tissue regeneration (PTR) [4]. Various therapeutic interventions are utilized clinically to treat periodontitis, including removing plaque and calculus by scaling and root planning or removing the necrotic tissues and initiating guided tissue regeneration (GTR) by periodontal surgery [5]. However, it seems that these therapies can only delay tooth loss with a small amount of PTR, which is unsatisfactory for both patients and dentists [6]. To date, the exploration of new PTR therapies includes bone transplantation, allogeneic materials, GTR, and various growth factor-based treatments [6-8]. However, these strategies still cannot reliably regenerate intact periodontal tissue damaged by severe periodontitis [9].

Stem cell-based tissue engineering and regenerative medicine are considered promising treatment strategies for PTR [10-12]. Numerous preclinical studies have tested the feasibility, safety, and effectiveness of various stem cell products [13]. Currently, the most studied stem cells, mainly adipose tissue-derived stem cells (ADSCs) [14, 15], bone marrow-derived stem cells (BMSCs) [16-18], dental pulp-derived stem cells (DPSCs) [19-21], gingival-derived stem cells (GMSCs) [22], and periodontal ligament-derived stem cells (PDLS Cs) [23-26], have been assessed for experimental PTR in a variety of animal models [12]. Stem cells have been exploited for their ability to form multiple periodontal tissues under appropriate induction conditions [27]. In addition, the application of stem cells can not only reconstruct the appropriate alveolar bone but also induce newly formed cementum (NC) and periodontal ligament (PDL), which implies complete regeneration of the periodontal complex [28].

Systematic reviews and meta-analyses of preclinical studies can improve the reliability and accuracy of the research results, scientifically support the selection of treatments that should be given priority for clinical trials, and reduce the risk of failure in the transition from animal experiments to clinical trials [29].
Previously, six systematic reviews were conducted using narrative methods without meta-analysis, focusing on a single type of stem cell or the synthesis of multiple stem cells [30-35]. Only three systematic reviews and pairwise meta-analyses assessed the efficacy of stem cells in PTR, demonstrating that stem cell-based therapies generally had a favorable effect [36-38]. However, it is still uncertain whether there are differences in the efficacy of different sources of stem cells in PTR. In addition, these studies were not conclusive enough to generate clear hierarchies.

Hence, the aim of this systematic review and network metaanalysis (NMA) was to comprehensively compare and rank five kinds of stem cells we were interested in for periodontal defect models by evaluating data from published preclinical studies, including ADSCs, BMSCs, DPSCs, GMSCs, and PDLSCs, which will provide reliable evidence for the design of preclinical and clinical trials in the future.

\section{Methods}

This systematic review and NMA was reported according to the PRISMA for Network Meta-Analyses (PRIS MA-NMA) statement [39]. The protocol for this study was prepared and registered on the PROSPERO international prospective register of systematic reviews (registration number: CRD42020169202).

\subsection{Search strategy}

An electronic search was performed up to February 2020 in the following electronic bibliographic databases: MEDLINE (via PubMed), EMBASE, and Web of Science. Search strategies were developed for the three databases (See Supplementary Table 1 for details). The retrieval adopted the combination of Mesh terms and free-text terms. The reviewers traced the references of the included literature and relevant systematic reviews in order to supplement the potentially relevant studies manually. Two reviewers (QL and GY) independently performed literature retrieval and screening, with any discrepancies resolved by discussion. There were no language or date restrictions, and foreign language papers were translated if required.

\subsection{Eligibility criteria}

We followed the participants, interventions, comparisons, outcomes, and study (PICOS) design framework [40] to identify and include preclinical, controlled comparative studies of periodontal defects or periodontitis models that evaluated the therapeutic potential of stem cells for the outcomes of three quantitative histological indicators: newly formed alveolar bone (NB), NC, and newly formed PDL (NPDL). Five types of stem cells most commonly used in PTR were included in the 
present NMA: ADSCs, BMSCs, DPSCs, GMSCs, and PDLSCs. To maintain homogeneity across studies, the review focused on locally applied interventions, excluding systemically applied therapies. We also excluded non-research articles or studies (e.g., reviews, hypotheses, and editorials), studies using animal models accompanied by other diseases, and studies with duplicated data (we evaluated only the latest research). Clinical trials assessing PTR treated with stem cells were also included to summarize existing clinical evidence in a narrative approach.

\subsection{Data extraction}

For each eligible study, two reviewers (QL and GY) independently extracted the following items, when available: study characteristics (author and year of publication); animal model characteristics (species, strain, gender, age or weight, model type, defect size); description of interventions and comparators (stem cell type, cell source, cell passage number, cell number, administration route, administration method, duration, and cell carriers); and outcomes (quantification data of newly formed periodontal tissue, including alveolar bone, cementum, and PDL). When only graphical presentation was available, we used a validated graphical digitizer and open-source program (Web Plot Digitizer, version 4.2, Ankit Rohatgi) to obtain values for mean and standard deviation (SD) or standard error of mean (SEM) under high magnification. When the extracted data existed in the form of medians and quartile differences, we used Hozo's formulas to transform them into mean and SD [41]. The two reviewers then cross-checked the data and resolved disagreements by discussion with a third reviewer (HD). In case of missing or unclear information, the corresponding authors of the papers were contacted via email.

\subsection{Quality assessment}

Two independent reviewers (QL and GY) evaluated the quality of each included preclinical study and risk of bias with adjudication by a third reviewer (HD), using a modified Systematic Review Centre for Laboratory Animal Experimentation (SYRCLE) risk of bias tool [42]. The tool includes ten defined criteria (Supplementary Table 2), including (1) sequence generation, (2) baseline characteristics, (3) allocation concealment, (4) random housing, (5) blinding against performance bias, (6) random outcome assessment, (7) blinding against detection bias, (8) incomplete outcome data, (9) selective outcome reporting, and (10) other sources of biases. We used "yes," "no," and "unclear" to judge the low risk of bias, high risk of bias, and insufficient details reported to assess the risk of bias properly, respectively.

\subsection{Statistical analysis}

For each direct comparison, we did pairwise metaanalyses through Stata software 16.0/MP (StataCorp, College Station, TX). We calculated the standardized mean difference (SMD) for continuous outcomes with 95\% credible intervals (CI). Statistical heterogeneity was assessed in each pairwise comparison with the visual inspection of forest plots and $I^{2}$ statistic [43].

We performed NMA using the multivariate metaanalysis model through Stata [44]. For this analysis, we used the "network" and "mvmeta" suite of Stata commands [45, 46]. We presented results from NMA as summary relative effect sizes as SMD for each possible pair of treatments. Network diagrams were drawn to depict the evidence for the outcomes. The size of the treatment nodes reflects the number of defects allocated to each treatment, while the thickness of the edges reflects the number of studies informing each comparison. Forest plots and league tables of all pairwise comparisons were prepared to summarize treatment comparisons for each outcome. We estimated the ranking probabilities of each intervention being ranked at different ranking positions and then calculated the surface under the cumulative ranking curve (SUCRA) to summarize the treatment hierarchy [47]. We assumed a common heterogeneity variance in the NMA. The assessment in the entire network was based on the magnitude of the heterogeneity variance parameter $\left(\tau^{2}\right)$ estimated from the NMA models. We assessed the statistical inconsistency between direct and indirect sources of evidence globally and locally. To evaluate the presence of inconsistency globally, we used the "design-by-treatment" model as described by Higgins [48]. Using this approach, we judged the presence of inconsistency from any source in the entire network based on a chi-square test. To evaluate the presence of inconsistency locally, we used the nodesplitting approach [49] and loop-specific approach [50].

\section{Results}

\subsection{Description of the included studies}

The modified PRISMA flowchart in Fig. 1 summarizes the details of the study selection process used to obtain eligible studies [40]. We identified 2252, 1391, and 2309 articles from MEDLINE, EMBASE, and Web of Science databases, respectively. In addition, we also obtained ten potentially eligible studies from relevant reviews. Overall, 4012 articles were identified after eliminating 1950 duplicate articles. Based on the abstract and title reviews, 3810 articles were excluded. After reviewing the full texts of the remaining 202 articles, 60 articles met our eligibility criteria for systematic review and NMA (Supplementary Table 3 shows the references and reasons for exclusion) [1525, 51-99]. 


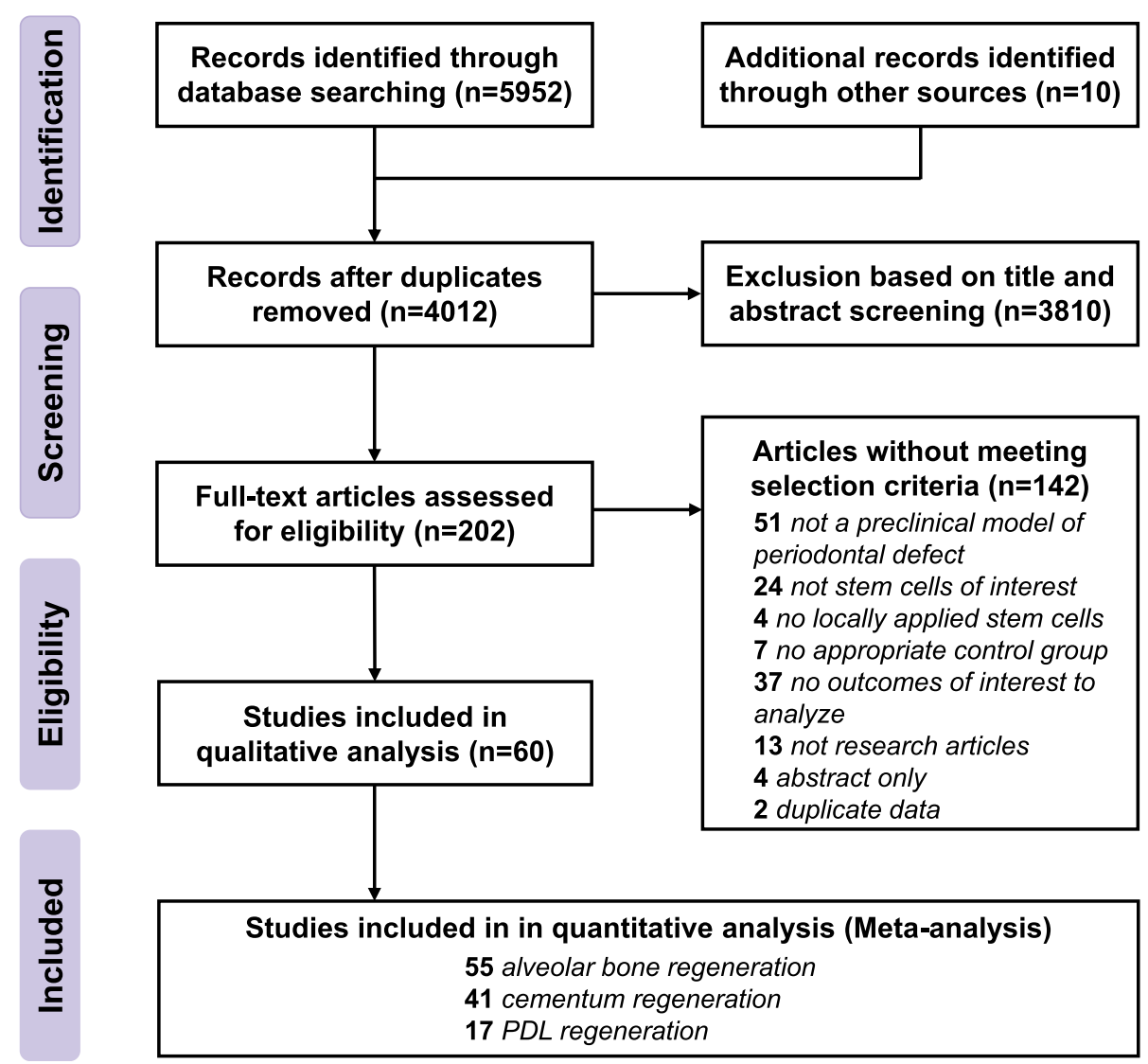

Fig. 1 Flowchart of the study selection process according to the PRISMA guidelines. "Other sources" refer to a manual search of bibliographies of the included studies and relevant systematic reviews. Down arrows indicate the progression of studies that passed the previous criteria. Side arrows indicate the number of studies excluded at each stage

The characteristics of each included study are summarized in Supplementary Table 4 and Supplementary Table 5. Among the 60 preclinical studies, 53 had two arms, six had three arms, and one had four arms. Animal models varied by species, such that $51.67 \%$ of the studies used canine models (e.g., beagle dogs and mongrel dogs), 28.33\% used rodents (e.g., Sprague Dawley rats, athymic nude rats, and Wistar rats), $16.67 \%$ used swine (e.g., minipigs), and $3.33 \%$ used ovine. The periodontal defect models included mainly intrabony defects (21.67\%), furcation defects (26.67\%), and fenestration defects $(16.67 \%)$. These studies evaluated the effect of stem cells from five different sources for PTR, including PDLS Cs $(50.00 \%)$, BMSCs (33.33\%), ADSCs (10.00\%), DPSCs (10.00\%), and GMSCs (8.33\%). Among the 60 studies, 46.67\% used autologous stem cells, 38.33\% used allogeneic stem cells, and $20.00 \%$ used xenogeneic stem cells.

\subsection{Quality of the included studies}

The SYRCLE risk of bias assessment is shown in Fig. 2 (overall) and Supplementary Fig. 1 (individual studies). Most studies reported the baseline characteristics and avoided attrition bias. Only 20 studies (32.79\%) were judged as having a low risk of blinding against detection bias. A high risk of bias was rare in any domain. However, few studies have attempted to report sequence generation, allocation concealment, random housing, blinding against performance bias, random outcome assessment, and other sources of bias; thus, unclear assessments were common.

\subsection{Outcomes}

Among the three histological indicators used as study effect sizes in the present NMA, NB was used to illustrate the effect size for stem cell administration in $91.67 \%$ of the 60 studies, $68.33 \%$ of the studies reported NC and $28.33 \%$ of the studies reported NPDL. Figure 3 presents the network plots of each outcome and demonstrates that the two most common comparisons were between PDLSCs and cell carriers $(\mathrm{CCs})$, followed by BMSCs versus CCs.

\subsubsection{Pairwise meta-analyses}

We present our random-effects pairwise meta-analyses of alveolar bone, cementum, and PDL regeneration in 


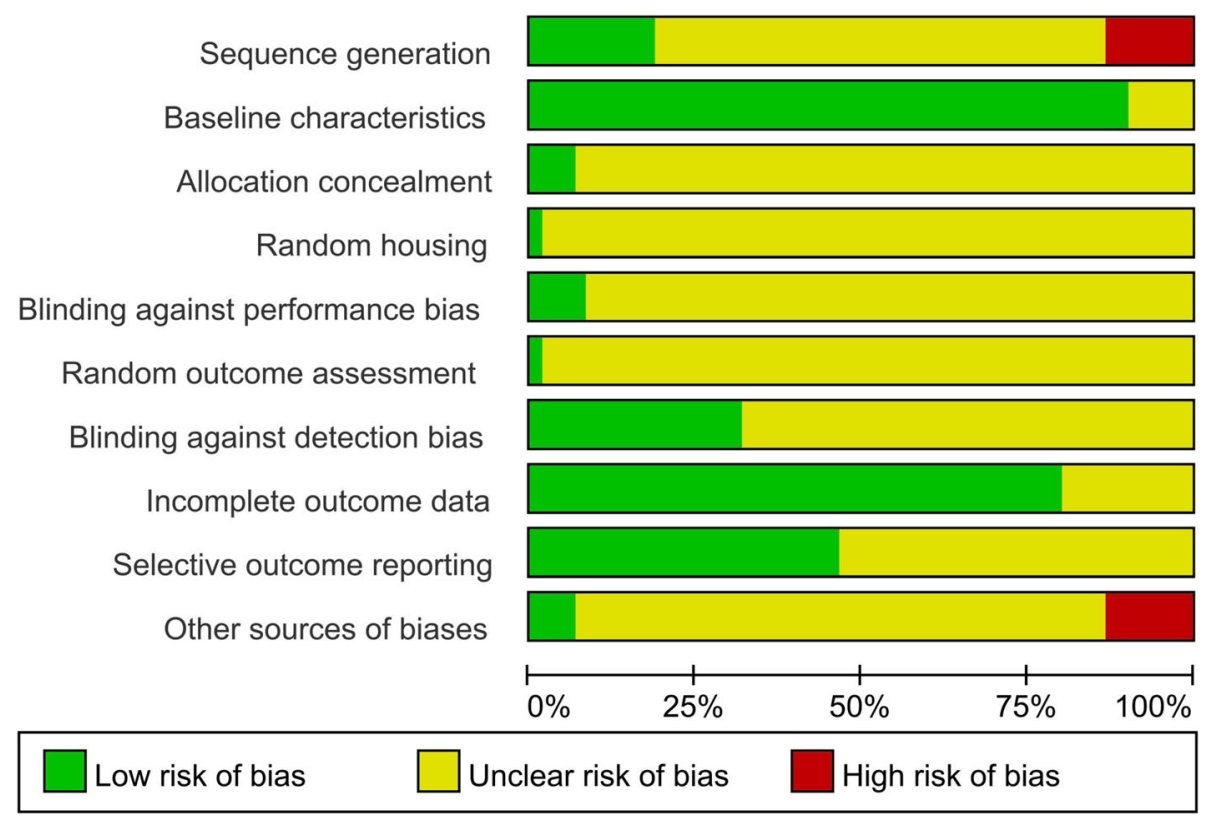

Fig. 2 Quality assessment of each risk of bias item presented as percentages across all included studies. The horizontal axis indicates the percentage of answers to the questions in the SYRCLE risk of bias tool. Each color represents a different level of bias: red for a high-risk, green for a low-risk, and yellow for an unclear risk of bias

Supplementary Fig. 2 and Fig. 4 (upper triangle). In terms of NB, PDLSCs (SMD 2.05, 95\% CI 1.40 to 2.71), BMSCs (SMD 2.05, 95\% CI 1.42 to 2.67), and DPSCs (SMD 3.10, 95\% CI 1.66 to 4.54 ) were statistically more efficacious than CCs; PDLSCs (SMD 1.81, 95\% CI 0.23 to 3.38) were superior to GMSCs. In terms of NC, PDLS Cs (SMD 2.05, 95\% CI 1.36 to 2.74), BMSCs (SMD 2.20, 95\% CI 1.37 to 3.04), ADSCs (SMD 1.62, 95\% CI 0.98 to 2.26), and DPSCs (SMD 1.04, 95\% CI 0.10 to 1.98) were statistically more efficacious than CCs; also, PDLSCs were superior to GMSCs (SMD 1.75, 95\% CI 0.24 to 3.26) and BMSCs (SMD 2.01, 95\% CI 0.82 to 3.20). For NPDL, PDLSCs (SMD 1.09, 95\% CI 0.41 to 1.77),
BMSCs (SMD 1.21, 95\% CI 0.45 to 1.97), and DPSCs (SMD 1.28, 95\% CI 0.31 to 2.25) were superior to CCs; and BMSCs (SMD 2.16, 95\% CI 0.53 to 3.79) were more efficacious than GMSCs. Notably, the number of studies involving direct comparisons of two types of stem cells is limited (no more than three) (Fig. 3).

\subsubsection{Network meta-analyses}

The lower triangles of Fig. 4 summarize the league tables with SMDs and 95\% CIs of interventions compared with each other. The results of the NMAs for all three outcomes are also presented as forest plots in Fig. 5 with estimated SMDs and 95\% CIs of

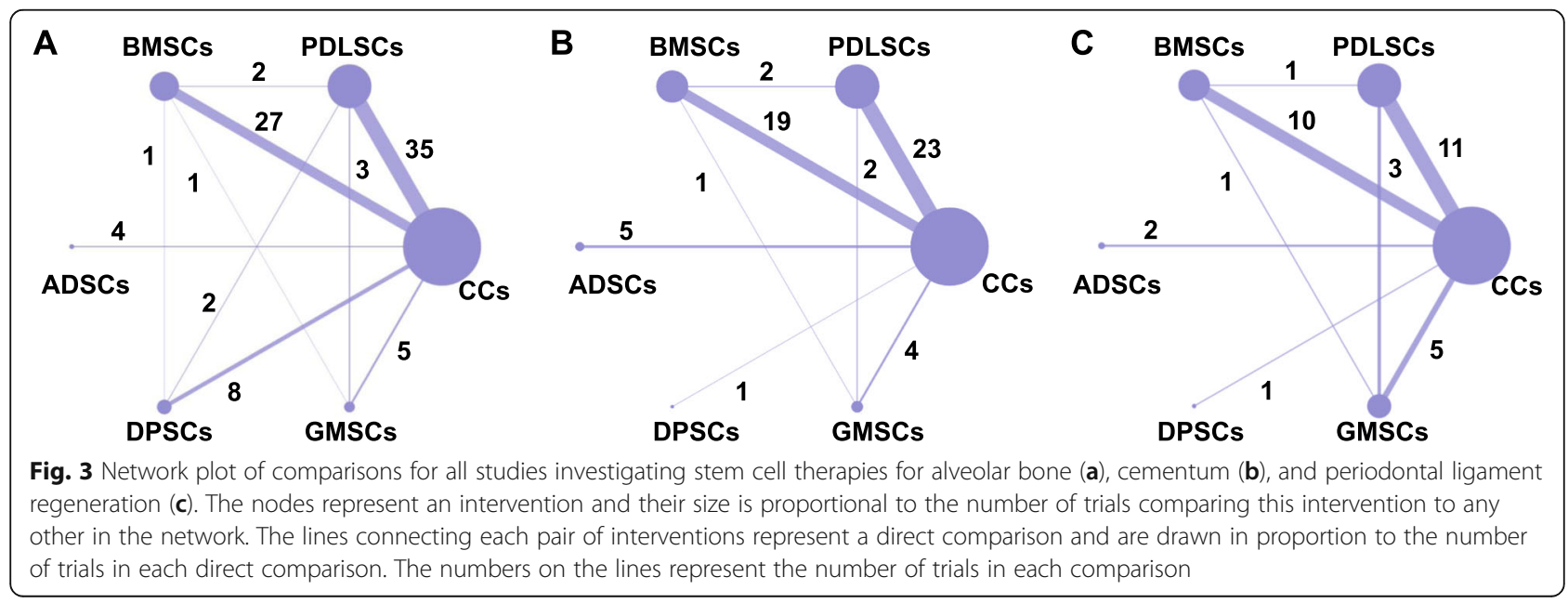




\begin{tabular}{|c|c|c|c|c|c|}
\hline PDLSCs & $\begin{array}{c}0.14 \\
(-0.79,1.06)\end{array}$ & NA & $\begin{array}{c}-2.34 \\
(-7.04,2.36)\end{array}$ & $\frac{\frac{-1.81}{(-3.38,-0.23)}}{(}$ & $\frac{-2.05}{(-2.71,-1.40)}$ \\
\hline $\begin{array}{c}0.00 \\
(-0.91,0.90)\end{array}$ & BMSCs & NA & $\begin{array}{c}1.04 \\
(-0.46,2.55)\end{array}$ & $\begin{array}{c}-1.21 \\
(-2.58,0.17)\end{array}$ & $\frac{-2.05}{(-2.67,-1.42)}$ \\
\hline $\begin{array}{c}0.43 \\
(-1.67,2.53)\end{array}$ & $\begin{array}{c}0.43 \\
(-1.70,2.56)\end{array}$ & ADSCs & NA & NA & $\begin{array}{c}-1.18 \\
(-2.51,0.14)\end{array}$ \\
\hline $\begin{array}{c}0.18 \\
(-0.98,1.34)\end{array}$ & $\begin{array}{c}0.18 \\
(-1.05,1.41)\end{array}$ & $\begin{array}{c}-0.25 \\
(-2.51,2.02)\end{array}$ & DPSCs & NA & $\frac{-3.10}{(-4.54,-1.66)}$ \\
\hline $\begin{array}{c}\frac{1.49}{(0.04,2.94)} \\
\end{array}$ & $\begin{array}{c}1.49 \\
(-0.03,3.02)\end{array}$ & $\begin{array}{c}1.06 \\
(-1.38,3.50)\end{array}$ & $\begin{array}{c}1.31 \\
(-0.42,3.04)\end{array}$ & GMSCs & $\begin{array}{c}-0.11 \\
(-1.75,1.54)\end{array}$ \\
\hline$\frac{1.87}{(1.24,2.51)}$ & $\frac{1.88}{(1.17,2.59)}$ & $\begin{array}{c}1.45 \\
(-0.56,3.46)\end{array}$ & $\begin{array}{c}\frac{1.69}{(0.64,2.75)} \\
\end{array}$ & $\begin{array}{c}0.39 \\
(-1.00,1.78)\end{array}$ & CCs \\
\hline PDLSCs & $\frac{-2.01}{(-3.20,-0.82)}$ & NA & NA & $\frac{-1.75}{(-3.26,-0.24)}$ & $\frac{-2.05}{(-2.74,-1.36)}$ \\
\hline $\begin{array}{c}0.07 \\
(-0.92,1.06)\end{array}$ & BMSCs & NA & NA & $\begin{array}{c}-0.76 \\
(-2.05,0.54)\end{array}$ & $\frac{-2.20}{(-3.04,-1.37)}$ \\
\hline $\begin{array}{c}0.63 \\
(-0.90,2.15)\end{array}$ & $\begin{array}{c}0.56 \\
(-1.03,2.16)\end{array}$ & ADSCs & NA & NA & $\frac{-1.62}{(-2.26,-0.98)}$ \\
\hline $\begin{array}{c}1.18 \\
(-1.70,4.07)\end{array}$ & $\begin{array}{c}1.12 \\
(-1.81,4.04)\end{array}$ & $\begin{array}{c}0.56 \\
(-2.56,3.67)\end{array}$ & DPSCs & NA & $\frac{-1.04}{(-1.98,-0.10)}$ \\
\hline $\begin{array}{c}0.99 \\
(-0.57,-2.56)\end{array}$ & $\begin{array}{c}0.93 \\
(-0.70,2.55)\end{array}$ & $\begin{array}{c}0.37 \\
(-1.61,2.35)\end{array}$ & $\begin{array}{c}-0.19 \\
(-3.34,2.96)\end{array}$ & GMSCs & $\begin{array}{c}-1.87 \\
(-3.81,0.06)\end{array}$ \\
\hline $\begin{array}{c}\frac{2.18}{(1.48,2.87)} \\
\end{array}$ & $\begin{array}{c}\frac{2.11}{(1.28,2.94)} \\
\end{array}$ & $\frac{1.55}{(0.18,2.91)}$ & $\begin{array}{c}0.99 \\
(-1.81,3.80)\end{array}$ & $\begin{array}{c}1.18 \\
(-0.25,2.62)\end{array}$ & CCs \\
\hline
\end{tabular}

\begin{tabular}{|c|c|c|c|c|c|}
\hline PDLSCs & $\begin{array}{c}-0.90 \\
(-2.21,0.42)\end{array}$ & NA & NA & $\begin{array}{c}-2.77 \\
(-6.41,0.88)\end{array}$ & $\frac{-1.09}{(-1.77,-0.41)}$ \\
\hline $\begin{array}{c}0.28 \\
(-0.78,1.35)\end{array}$ & BMSCs & NA & NA & $\frac{\frac{-2.16}{(-3.79,-0.53)}}{(}$ & $\frac{-1.21}{(-1.97,-0.45)}$ \\
\hline $\begin{array}{c}1.16 \\
(-0.60,2.91)\end{array}$ & $\begin{array}{c}0.87 \\
(-0.92,2.66)\end{array}$ & ADSCs & NA & NA & $\begin{array}{c}-0.50 \\
(-1.43,0.43)\end{array}$ \\
\hline $\begin{array}{c}0.47 \\
(-1.76,2.70)\end{array}$ & $\begin{array}{c}0.19 \\
(-2.07,2.44)\end{array}$ & $\begin{array}{c}-0.69 \\
(-3.31,1.93)\end{array}$ & DPSCs & NA & $\frac{-1.28}{(-2.25,-0.31)}$ \\
\hline$\frac{1.26}{(0.11,2.42)}$ & $\begin{array}{c}0.98 \\
(-0.27,2.22)\end{array}$ & $\begin{array}{c}0.11 \\
(-1.74,1.96)\end{array}$ & $\begin{array}{c}0.79 \\
(-1.50,3.09)\end{array}$ & GMSCs & $\begin{array}{c}-0.82 \\
(-2.08,0.43)\end{array}$ \\
\hline$\frac{1.69}{(0.92,2.47)}$ & $\frac{1.41}{(0.56,2.26)}$ & $\begin{array}{c}0.54 \\
(-1.04,2.12)\end{array}$ & $\begin{array}{c}1.22 \\
(-0.86,3.31)\end{array}$ & $\begin{array}{c}0.43 \\
(-0.52,1.39)\end{array}$ & CCs \\
\hline
\end{tabular}

Treatment

NMA (SMD with $95 \% \mathrm{Cl}$ )

Pairwise meta-analysis (SMD with 95\% Cl)

Fig. 4 Summary treatment effects from network meta-analysis and pairwise meta-analysis for alveolar bone (a), cementum (b), and periodontal ligament regeneration (c) likelihood. Comparisons should be read from left to right. The estimate is located at the intersection of the columndefining treatment and the row-defining treatment. The lower triangles of the league tables represent the NMA results, and the upper triangles are the pairwise meta-analysis results. For the NMA and pairwise meta-analysis results, an SMD value higher than 0 favors column-defining treatment. For SMDs of comparisons in the opposing direction, the opposite numbers should be taken. Significant results are bold and underscored. $\mathrm{NA}=$ not applicable, no preclinical studies making direct comparisons 


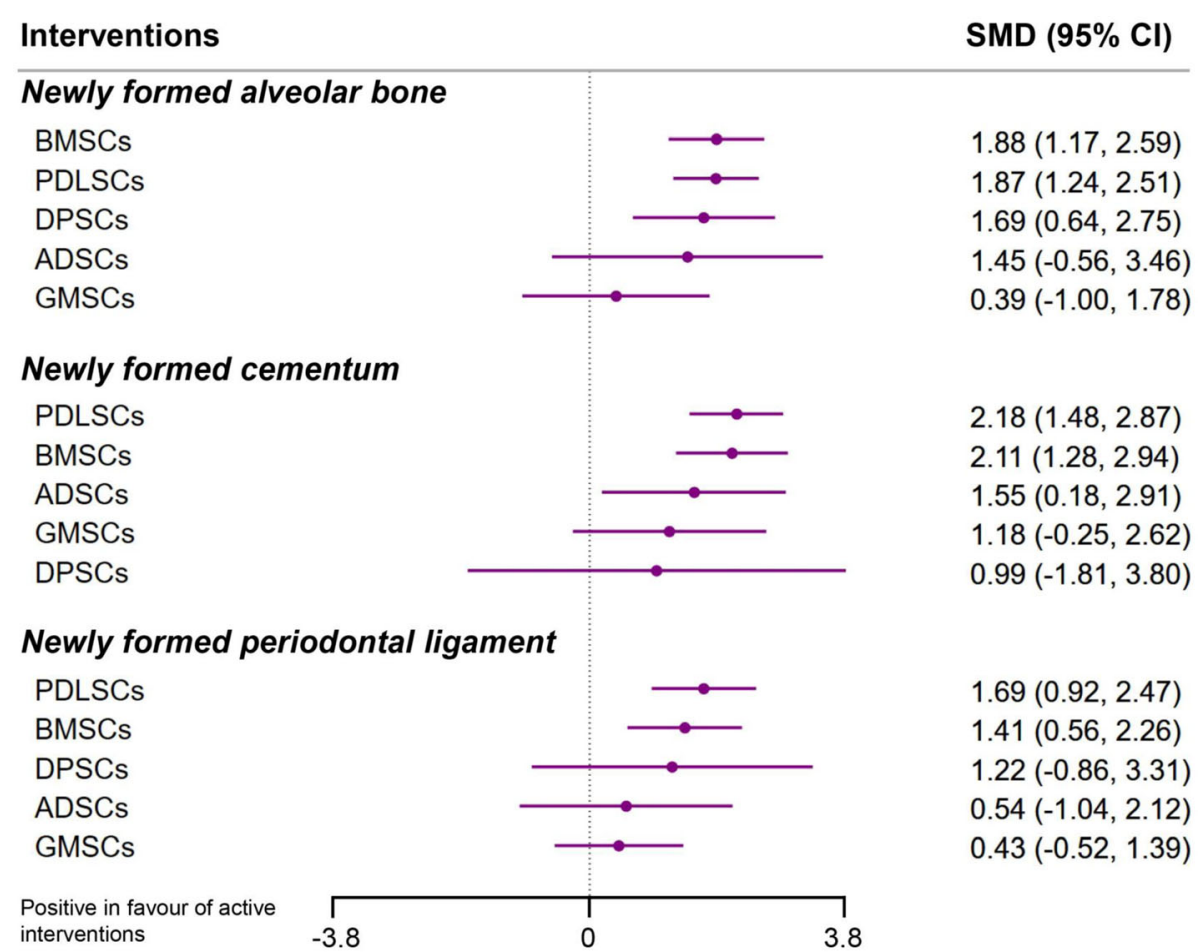

Fig. 5 Network meta-analyses of stem cell therapies compared to cell carrier-only controls for each outcome. Points signify SMD estimates, and lines mark their $95 \% \mathrm{Cls}$. SMDs of more than 0 favor stem cells over cell carrier-only control. All single $95 \%$ Cls crossing the vertical line (0) imply no significant effect on the alveolar bone, cementum, or periodontal ligament regeneration. The SMDs with 95\% Cls were estimated from the random-effects consistency model

interventions compared with a cell carrier-only control. NMA showed that compared with CCs, PDLSCs (SMD 1.87, 95\% CI 1.24 to 2.51), BMSCs (SMD 1.88, 95\% CI 1.17 to 2.59 ), and DPSCs (SMD 1.69, 95\% CI 0.64 to 2.75) increased NB; PDLSCs showed an increase of 1.49 (95\% CI 0.04 to 2.94) in NB compared with GMSCs. In terms of NC, PDLSCs (SMD 2.18, 95\% CI 1.48 to 2.87), BMSCs (SMD 2.11, 95\% CI 1.28 to 2.94 ), and ADSCs (SMD 1.55, 95\% CI 0.18 to 2.91) were more effective than CCs. Regarding NPDL, trends favored PDLSCs (SMD 1.69, 95\% CI 0.92 to 2.47 ) and BMSCs (SMD 1.41, 95\% CI 0.56 to 2.26) when compared to CCs and favored PDLSCs (SMD $1.26,95 \%$ CI 0.11 to 2.42 ) when compared to GMSCs.

Figure 6 shows the cumulative probabilities for each intervention being at each possible rank and presents the treatment hierarchies with the SUCRA; the larger the SUCRA is, the higher its rank among all available interventions. Supplementary Table 6 also summarizes the SUCRA, mean probabilities of being best, and mean rank. The ranking in Fig. 6 indicates the cumulative probability of being the best intervention, the secondbest intervention, the third-best intervention, etc. A
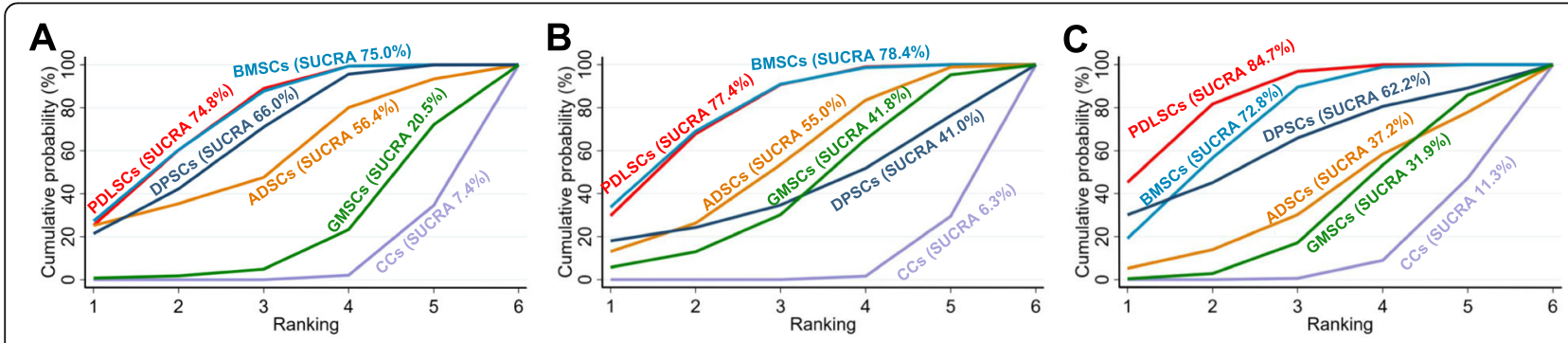

Fig. 6 Cumulative ranking plots comparing each of the stem cells for alveolar bone (a), cementum (b), and periodontal ligament regeneration (c), Ranking indicates the cumulative probability of being the best intervention, the second-best intervention, the third-best intervention, etc. The $x$ axis shows the relative ranking, and the $y$-axis shows the cumulative probability of each ranking. The surface underneath this cumulative ranking line (SUCRA) was estimated; the larger the SUCRA, the higher its rank among all available treatments 
SUCRA value of $100 \%$ means the stem cell is the best, and a SUCRA value of $0 \%$ means the intervention is the worst. The results of ranking probabilities revealed that the two highest-ranked interventions were PDLSCs and BMSCs in all three outcomes (Fig. 6 and Supplementary Table 6). Specifically, the highest-ranked stem cells in NB were BMSCs (SUCRA 75.0) and PDLSCs (SUCRA 74.8\%); DPSCs (SUCRA 66.0\%) ranked third followed by ADSCs (SUCRA 56.4\%), GMSCs (SUCRA 20.5\%), and CCs (SUCRA 7.4\%). In terms of NC, BMSCs (SUCRA 78.4\%) and PDLSCs (SUCRA 77.4\%) ranked two highest followed by ADSCs (SUCRA 55.0\%), GMSCs (SUCRA 41.8\%), DPSCs (SUCRA 41.0\%), and CCs (SUCRA 6.3\%). PDLSCs (SUCRA 84.7\%) ranked first in PDL regeneration followed by BMSCs (SUCRA 72.8\%), DPSCs (SUCRA 62.2\%), ADSCs (SUCRA 37.2\%), GMSCs (SUCRA 31.9\%), and CCs (SUCRA 11.3\%).

No evidence of global inconsistency in any outcomes was observed using the "design-by-treatment" models (Supplementary Table 7). The node-splitting approach separated evidence on a particular comparison into direct and indirect evidence. Local inconsistency from the node-splitting model showed significant differences only between CCs vs. PDLSCs and PDLSCs vs. GMSCs for both NC and NPDL but not for NB (Supplementary Table 7). When at least three interventions were compared with each other in a network that formed a closed path, the loop-specific approach compared indirect evidence with direct evidence, and their differences defined the inconsistency factor (IF). Subsequently, the magnitude of the IF, 95\% CI of IF, and a loop-specific $z$-test could be used to infer the presence of inconsistency in each loop. The evaluation of inconsistency using loopspecific heterogeneity estimates revealed that there was no inconsistency in each loop (Supplementary Table 7 and Supplementary Fig. 3).

\subsection{A narrative synthesis of published clinical trials}

Among the literature we searched, we finally included eight published clinical trials for narrative synthesis, in which PTR was achieved by using stem cells (Table 1) [100-107]. The types of stem cells used included PDLS Cs (three studies), BMSCs (two studies), DPSCs (two studies), and umbilical cord mesenchymal stem cells (UMSCs, one study). Only three studies were designed as randomized controlled trials (RCTs), in which DPSCs [105] and UMSCs [103] were found to have significantly increased PTR compared with that of the control group; although PDLSCs could increase the height of alveolar bone in periodontal defects, no statistically significant differences were detected between the cell group and the control group [102]. Five single-arm studies also demonstrated that PDLSCs, BMSCs, and DPSCs could significantly improve the clinical parameters of periodontal regeneration [100, 101, 104, 106, 107]. Additionally, four studies reported the safety of stem cells, and the results showed that using autologous BMSCs and PDLSCs to treat periodontal defects was safe and did not produce significant adverse effects [101, 102, 104, 106].

\section{Discussion}

\subsection{Principal finding}

To the best of our knowledge, this systematic review and NMA represents the first and most comprehensive synthesis of data on stem cell-based therapies for preclinical PTR. We mainly focused on five promising stem cell types, among which PDLSCs and BMSCs appeared to be the most effective and the most well-documented stem cell-based therapies for alveolar bone, cementum, and PDL. In addition, direct and indirect comparisons revealed that DPSCs were more efficacious than CCs in terms of bone regeneration and that ADSCs were superior to CCs in terms of cementum regeneration. No apparent inconsistency between the results of direct comparison and indirect comparison was found. However, although a broad range of stem cells had been assessed, there was an unclear risk of bias, and few head-to-head comparisons were performed.

\subsection{Implications for future preclinical and clinical research}

\subsubsection{Accessibility of stem cells}

In addition to effectiveness, another critical issue is the accessibility of stem cells. The treatment of periodontal defects requires numerous cells $\left(5 \times 10^{4}\right.$ to $2 \times 10^{8}$ cells per defect), which is sometimes difficult to obtain from a single patient. Although stem cells can be expanded in vitro, their ability to self-renew and proliferate is typically diminished during passage [108]. In addition, periodontitis is not a terminal disease and treatment should balance risks and benefits simultaneously. Therefore, the best approach to acquiring stem cells should meet the requirements of sufficient quantity, painless and straightforward sampling, and low risk of complications.

Since PDLSCs and DPSCs are not always conveniently available in clinical practice, it is crucial to develop new sources of stem cells for PTR. Compared with other dental stem cells, GMSCs are easier to obtain, stable in morphology, uniform in morphology, rapid in proliferation, and able to maintain normal karyotype and telomerase activity in long-term culture [109]. However, our NMA showed that there is no evidence that GMSCs are statistically superior to the control group in periodontal regeneration. Nondental stem cells are potential substitutes for dental stem cells. BMSCs are the most widely studied type of stem cell and have proven to be effective in our NMA. ADSCs can be easily isolated in large numbers from resected adipose tissue or by 
Table 1 Characteristics of the included clinical trials

\begin{tabular}{|c|c|c|c|c|c|c|c|}
\hline Study & $\begin{array}{l}\text { Baseline of } \\
\text { participants }\end{array}$ & $\begin{array}{l}\text { Defect } \\
\text { type }\end{array}$ & Stem cells & $\begin{array}{l}\text { Cell } \\
\text { carrier }\end{array}$ & Control & Major finding & $\begin{array}{l}\text { Study } \\
\text { design }\end{array}$ \\
\hline $\begin{array}{l}\text { Aimetti } \\
2018[100]\end{array}$ & $\begin{array}{l}11 \text { participants with } 11 \\
\text { defects; mean age } \\
51.2 \pm 6.1 \text { years; five } \\
\text { males and six females; } \\
\text { Italia }\end{array}$ & $\begin{array}{l}\text { Intrabony } \\
\text { defect }\end{array}$ & $\begin{array}{l}\text { Autologous DPSCs } \\
\text { isolated from one } \\
\text { vital tooth of the } \\
\text { patients }\end{array}$ & $\begin{array}{l}\text { Collagen } \\
\text { sponge }\end{array}$ & Self-control & $\begin{array}{l}\text { The application of DPSCS } \\
\text { significantly improved } \\
\text { clinical (PD, AL) and } \\
\text { radiographic parameters } \\
\text { (BF) of periodontal } \\
\text { regeneration. }\end{array}$ & $\begin{array}{l}\text { Single-arm } \\
\text { and single- } \\
\text { center clin } \\
\text { ical study }\end{array}$ \\
\hline $\begin{array}{l}\text { Baba } \\
2016 \text { [101] }\end{array}$ & $\begin{array}{l}10 \text { participants with ten } \\
\text { defects; mean age } \\
48.4 \text { years; three males } \\
\text { and seven females; } \\
\text { Japan }\end{array}$ & $\begin{array}{l}\text { Intrabony } \\
\text { defect }\end{array}$ & $\begin{array}{l}\text { Autologous BMSCs } \\
\text { isolated from } \\
\text { patient iliac crest } \\
\text { marrow aspirate }\end{array}$ & $\begin{array}{l}\text { PRP and a } \\
\text { composed } \\
\text { of PLA } \\
\text { resin fibers }\end{array}$ & $\begin{array}{l}\text { Two healthy } \\
\text { teeth per } \\
\text { patient were } \\
\text { used as the } \\
\text { control }\end{array}$ & $\begin{array}{l}\text { All three clinical parameters } \\
\text { (PD, AL, and LBG) improved } \\
\text { significantly. No clinical safety } \\
\text { problems attributable to } \\
\text { BMSCs were identified. }\end{array}$ & $\begin{array}{l}\text { Single-arm } \\
\text { and single- } \\
\text { center clin } \\
\text { ical study }\end{array}$ \\
\hline $\begin{array}{l}\text { Chen } \\
2016 \text { [102] }\end{array}$ & $\begin{array}{l}30 \text { participants with } 41 \\
\text { defects; } 30.04 \pm 7.90 \text { years } \\
\text { for the control group; } \\
26.05 \pm 4.44 \text { for cell } \\
\text { group; Male and } \\
\text { Female; China }\end{array}$ & $\begin{array}{l}\text { Intrabony } \\
\text { defect }\end{array}$ & $\begin{array}{l}\text { Autologous PDLSCS } \\
\text { isolated from the } \\
\text { third molars of the } \\
\text { patients }\end{array}$ & Bio-oss & $\begin{array}{l}21 \text { defects } \\
\text { treated with } \\
\text { GTR and } \\
\text { Bio-oss } \\
\text { without } \\
\text { stem cells }\end{array}$ & $\begin{array}{l}\text { Each group showed a } \\
\text { significant increase in the } \\
\text { alveolar bone height, while } \\
\text { no statistically significant } \\
\text { differences were detected } \\
\text { between the cell group and } \\
\text { the control group. Using } \\
\text { autologous PDLSCs is safe } \\
\text { and does not produce } \\
\text { significant adverse effects. }\end{array}$ & $\begin{array}{l}\text { Single- } \\
\text { center RCTs }\end{array}$ \\
\hline $\begin{array}{l}\text { Dhote } \\
2015 \text { [103] }\end{array}$ & $\begin{array}{l}14 \text { participants with } \\
24 \text { defects; mean age } \\
32.62 \pm 6.99 \text { years; } \\
\text { eight males and } \\
\text { six females; India }\end{array}$ & $\begin{array}{l}\text { Intrabony } \\
\text { defect }\end{array}$ & $\begin{array}{l}\text { Allogeneic UMSCs } \\
\text { isolated from } \\
\text { human umbilical } \\
\text { cord }\end{array}$ & $\begin{array}{l}\beta \text {-TCP and } \\
\text { rh-PDGF-BB }\end{array}$ & $\begin{array}{l}14 \text { control sites } \\
\text { were treated } \\
\text { by an open } \\
\text { flap } \\
\text { debridement } \\
\text { only }\end{array}$ & $\begin{array}{l}\text { Using stem cells cultured on } \\
\beta \text {-TCP in combination with } \\
\text { rh-PDGF-BB resulted in a } \\
\text { significant added benefit in } \\
\text { terms of AL gains, PD } \\
\text { reductions, more excellent } \\
\text { radiographic BF, and } \\
\text { improvement in LBG } \\
\text { compared to the control } \\
\text { group. }\end{array}$ & $\begin{array}{l}\text { Single- } \\
\text { center RCTs }\end{array}$ \\
\hline $\begin{array}{l}\text { Feng } \\
2010 \text { [104] }\end{array}$ & $\begin{array}{l}\text { Three participants with } \\
16 \text { defects; } 25,25, \\
\text { and } 29 \text { years; Male; } \\
\text { China }\end{array}$ & $\begin{array}{l}\text { Intrabony } \\
\text { defect }\end{array}$ & $\begin{array}{l}\text { Autologous PDLSCS } \\
\text { obtained from } \\
\text { third molars }\end{array}$ & $\begin{array}{l}\text { Bone grafting } \\
\text { material CALCITITE } \\
4060-2\end{array}$ & Self-control & $\begin{array}{l}\text { Clinical examination (PD, AL, } \\
\text { and GR) indicated that PDLSCs } \\
\text { might provide therapeutic } \\
\text { benefits for periodontal defects. } \\
\text { All treated patients showed no } \\
\text { adverse effects during the } \\
\text { follow-up. }\end{array}$ & $\begin{array}{l}\text { Single-arm } \\
\text { and single- } \\
\text { center clin } \\
\text { ical study }\end{array}$ \\
\hline $\begin{array}{l}\text { Ferrarotti } \\
2018[105]\end{array}$ & $\begin{array}{l}29 \text { participants with } \\
29 \text { defects; mean age } \\
50.7 \pm 8.5 \text { years; } 13 \\
\text { males and } 14 \\
\text { females; Italia }\end{array}$ & $\begin{array}{l}\text { Intrabony } \\
\text { defect }\end{array}$ & $\begin{array}{l}\text { Autologous DPSCs } \\
\text { isolated from one } \\
\text { vital tooth of the } \\
\text { patients }\end{array}$ & Collagen sponge & $\begin{array}{l}14 \text { control sites } \\
\text { were filled with } \\
\text { collagen } \\
\text { sponge alone }\end{array}$ & $\begin{array}{l}\text { Application of DPSCs significantly } \\
\text { improved clinical parameters } \\
\text { of periodontal regeneration } \\
\text { (PD, AL, and BF) } 1 \text { year after } \\
\text { treatment. }\end{array}$ & $\begin{array}{l}\text { Single- } \\
\text { center RCTs }\end{array}$ \\
\hline $\begin{array}{l}\text { Iwata } \\
2018 \text { [106] }\end{array}$ & $\begin{array}{l}10 \text { participants with } \\
14 \text { defects; mean age } \\
46 \pm 12 \text { years; five } \\
\text { males and five } \\
\text { females; Japan }\end{array}$ & $\begin{array}{l}\text { Intrabony } \\
\text { defect }\end{array}$ & $\begin{array}{l}\text { Autologous PDLSCs } \\
\text { isolated from the } \\
\text { third molars of the } \\
\text { patients }\end{array}$ & $\beta-T C P$ & Self-control & $\begin{array}{l}\text { Clinical parameters (PD, AL) } \\
\text { and radiographic assessment } \\
\text { (bone height) were improved } \\
\text { in all } 10 \text { cases at } 6 \text { months after } \\
\text { the transplantation. These } \\
\text { therapeutic effects were sustained } \\
\text { during a mean follow-up period } \\
\text { of } 55 \pm 19 \text { months, and there } \\
\text { were no serious adverse events. }\end{array}$ & $\begin{array}{l}\text { Single-arm } \\
\text { and single- } \\
\text { center clin } \\
\text { ical study }\end{array}$ \\
\hline $\begin{array}{l}\text { Yamada } \\
2006 \text { [107] }\end{array}$ & $\begin{array}{l}\text { One participant with } \\
\text { one defect; } 54 \text { years; } \\
\text { Female; Japan }\end{array}$ & $\begin{array}{l}\text { Intrabony } \\
\text { defect }\end{array}$ & $\begin{array}{l}\text { Autologous BMSCs } \\
\text { isolated from } \\
\text { patient iliac crest } \\
\text { marrow aspirate }\end{array}$ & $\begin{array}{l}\text { PRP and } \\
\text { thrombin-calcium } \\
\text { chloride }\end{array}$ & $\begin{array}{l}\text { The patient's } \\
\text { contralateral } \\
\text { homonymous } \\
\text { teeth }\end{array}$ & $\begin{array}{l}\text { BMSCs/PRP gel could be } \\
\text { clinically effective in reducing } \\
\text { PD, improving AL in intrabony } \\
\text { lesions. }\end{array}$ & $\begin{array}{l}\text { Single-arm } \\
\text { and single- } \\
\text { center clin } \\
\text { ical study }\end{array}$ \\
\hline
\end{tabular}

Abbreviations: $A L$ attachment level, $B F$ bone filling, $\beta-T C P$ beta-tricalcium phosphate, $G R$ gingival recession, $L B G$ linear bone growth, $P D$ probing depth, $P L A$ poly-L-lactic acid, PRP platelet-rich plasma, RCTs randomized controlled trials, $r h$-PDGF-BB recombinant human platelet-derived growth factor-BB

liposuction and show significant similarity with BMSCs in gene expression and osteogenic capacity [24, 110]. Data analyzed in the present NMA also showed that ADSCs are beneficial in cementum regeneration. Induced pluripotent stem cells (iPSCs), another type of stem cell, were not included in our NMA because a few research has evaluated iPSCs and quantitative data are lacking, but the potential curative effect, application value, and potential to avoid ethical issues by using iPSCs cannot be ignored. Both dental cells and 
nondental cells have been successfully reprogrammed into iPSCs, which can differentiate into multiple cell types [111-114].

\subsubsection{Insufficient evidence for other potential stem cells} Our NMA suggests that PDLSCs and BMSCs comprised the largest share $(80.00 \%)$ of stem cell-based therapies investigated in experimental PTR over the last decade. Both direct and indirect comparisons of PDLSCs and BMSCs concluded a beneficial therapeutic effect in PTR. Clinical studies have also suggested their effectiveness (Table 1) [101, 102, 106, 115]. In contrast, it is worth emphasizing that only a few quantitative analyses of GMSCs and ADSCs were included in the present NMA (five for GMSCs and six for ADSCs). There are differences between the results of different studies, which may be due to the substantial heterogeneity of the studies. For instance, GMSCs were found to be beneficial to alveolar bone regeneration in one out of five studies, while two of three studies showed that GMSCs were beneficial to cementum regeneration, and two of four studies showed that GMSCs favored PDL regeneration (Supplementary Fig. 2). iPSCs, which were reprogrammed from male human foreskin fibroblasts by four transfected transcription factors (Oct4, Sox2, Nanog, and Lin28), demonstrated the ability to initiate alveolar bone, cementum, and PDL regeneration in a periodontal fenestration defect model of rodents [111]. In addition, a recent study has shown that iPSCs, reprogrammed from fibroblasts by transducing retroviral vectors encoding four transcription factors (Oct-4, Sox2, Klf4, and c-Myc), can differentiate into osteocyte-like cells and promote periodontal bone regeneration [112]. Yang et al. [116] improved the regeneration of furcation defects in an experimental periodontitis model by transplanting swine embryonic stem cells (ESCs) and found that the experimental site had differentiated into new PDL and cementum. A clinical trial has shown that the use of UMSCs can significantly improve clinical parameters that reflect periodontal status (Table 1) [103]. Combined with treated dentin matrix particles, cell sheets derived from human dental follicle stem cells (DFSCs) can promote the proliferation and osteogenic differentiation of human BMSCs, and achieve an optimized effect of PTR in beagle dogs with one-wall periodontal intrabony defects [117]. However, due to the limited number of related studies, additional preclinical studies are required in future work to further ensure the efficacy of GMSCs, ADSCs, iPSCs, ESCs, UMSCs, and DFSCs in PTR.

\subsubsection{Poorly connected network}

Most of the included studies were two-arm trials, and few studies (11.67\%) compared stem cells from different sources simultaneously. The evidence map also shows that although PDLSCs and BMSCs are currently the most preclinical studies, there is little evidence for a direct comparison between them, and the whole network diagrams are poorly connected (Fig. 3). Although NMA provides indirect evidence, the evidence intensity of indirect comparisons is weaker than that of direct comparisons, which may lead to deviations in comparison results. Multiple-arm studies or studies providing evidence that addresses key unresolved issues should be performed in the future to make the whole network diagram more complete.

\subsubsection{Multiple preclinical animal models}

The consequences and implications of the present NMA may be restricted to animal models of periodontal defects and may not be suitable for direct extrapolation to periodontal defects in humans. The differences between preclinical models and human diseases make their relevance to one another debatable.

The development of periodontitis can be divided into different stages, including the formation of pathogenic biofilms, the stimulation/invasion of oral microorganisms and/or their derivatives, the induction of destructive host response in gingival tissue, and the destruction of supporting tissue and alveolar bone [1]. The periodontal defect caused by periodontitis is a chronic inflammatory process in humans. In contrast, the most commonly used modeling methods in the studies included in the present NMA (accounting for 43/60) were the acute defect models created by surgical methods, including surgical dehiscence, fenestration, intrabony, and furcation defects (Supplementary Table 4). Although these models can mimic the defect morphology in humans, they do not exhibit the same microenvironment of chronic inflammation in the defects. In chronic defect models, the formation of natural periodontitis is induced by placing wires, ligatures, or impression material around the teeth. However, the defect areas produced by this method are difficult to standardize. In the included studies, another method was used that overcomes the shortcomings of the above two methods. Standardized defects were created surgically, in which foreign materials (e.g., impression materials, cotton balls saturated with anaerobic bacteria) or binding wires were placed around the affected teeth for a period of time to induce inflammation (Supplementary Table 4).

Multiple animal species, including canines (51.67\%), rodents $(28.33 \%)$, swine $(16.67 \%)$, and ovine $(3.33 \%)$, were used in the included studies. Compared with smaller animals, the dental anatomy of larger animals bears a closer resemblance to human dentoalveolar architecture, which allows for a more direct interpretation of the data and the translation of the acquired knowledge into clinical practice [118]. However, due to 
the issues of expansive, ethics, and the requirement of specialized breeding and maintenance facilities, the use of large animals is limited and should be reserved for the last phase of potential therapy validation [119]. In contrast, small animals (mainly rodents) are often used as a starting point for preliminary screening, and the results are then verified in large animals, which may eliminate the need for larger species before human trials [120].

\subsubsection{Biomaterials serve as stem cell delivery vehicles}

Our systematic review and NMA findings indicate that stem cells associated with suitable scaffolds may provide beneficial effects on PTR in human patients and preclinical animal models (Table 1 and Supplementary Table 4). As shown in Table 1, clinical trials mainly use scaffolds made of collagen (e.g., fibers, sheets, hydrogels, and sponges) and bone substitute (e.g., Bio-Oss, betatricalcium phosphate, and hydroxyapatite), which may be particularly beneficial due to their biocompatibility, biodegradability, and capability to promoting healing [121]. In contrast, the biomaterials used in preclinical experiments are more varied and novel, including but not limited to bone substitute, collagen, polymers, plasma-rich platelets, blood coagulum, enamel matrix derivative, gelatin, and hyaluronic acid (Supplementary Table 4). The diversity of CCs shows the clinical necessity of biomaterials, but it should also be noted that this diversity may lead to substantial heterogeneity in NMA.

The use of appropriate scaffold biomaterials as cell delivery vehicles can not only establish a suitable microenvironment to prolong the viability of stem cells but also provide essential factors to direct stem cell differentiation toward desired lineages [122, 123]. Besides, biomaterials synergize with tissue engineering in recapitulating cellular interactions [124]. In the complex microenvironment of the stem cell/material interface, cells and materials cooperatively dictate each other's fate: cells reconstruct their surroundings, while materials determine their fate by their inherent properties, such as adhesivity, stiffness, nanostructure, or degradability [123-125]. In addition, stem cells that come into contact with the materials can sense the characteristics of the material, integrate clues through signal propagation, and eventually translate parallel signal information into the decision of cell fate [125]. However, the significant disadvantages of most biomaterials for PTR are poor mechanical strength, weak adhesion to defective tissues, unpredictable cell-biomaterial interactions, immune reaction, low-efficiency cell seeding, and rapid/uncontrollable degradation $[35,126,127]$.

The type of defect, especially the number of involved alveolar bone walls, should be considered when choosing the method of cell delivery. When the lesions are retentive, liquid or gel scaffolds can be used without causing the cells to disperse $[15,16$, $25,66]$. When the lesions are large, the use of bone substitute can confine the cell-material complex to the surgical site and improve the regeneration process, such as by combining the stem cells and bone substitute or by transplanting the cell sheets attached with polymers to the root surface of the tooth and then filling the bone defects with bone substitute [20, 24, 61, 87].

The treatment of stem cells and biomaterials provides the possibility for substantial PTR. However, although a large number of biomaterials have been widely assessed in a laboratory setting, bone substitutes and collagen membranes are still the most commonly used biomaterials to fill periodontal defects in a clinical setting. Therefore, we suggest that future studies should compare stem cellbased therapies with current clinical conventional periodontal therapies and determine the appropriate type of cell-supporting scaffolds for different defects.

\subsection{Strengths and limitations of the study}

The strength of our study is that we comprehensively compared and ranked five different sources of stem cells for PTR. Compared with previous pairwise metaanalyses, the use of indirect comparisons within the present NMA adds additional information to the current evidence. Compared with periodontal probing and radiological observation techniques used in clinical studies, histology can be used in preclinical studies to analyze regenerative periodontal tissue more intuitively and objectively. Additionally, we included preclinical studies without language restrictions to avoid bias.

Our NMA had some limitations. First, although most of the studies tried to report baseline characteristics and avoid attrition bias, few studies provided enough information to determine how they precluded potential performance bias, detection bias, or reporting bias. Unclear risk of bias was common across studies, which should be considered when interpreting the results from the present NMA. Second, different animal strains, periodontal defect types, and CCs were included in the studies resulting in clinical heterogeneity. Substantial statistical heterogeneity was found in many comparisons of primary outcomes, which might be explained in part by experimental variability. We used a random-effects model to account for the expected heterogeneity. Third, although no evidence of global inconsistency was observed, there is a local inconsistency between the results of direct comparison and indirect comparison, which should be interpreted with caution. In addition, according to past research, funnel plots serving to detect the small-study effects can be severely distorted in pairwise comparisons based on the SMD summary measure [128]. We did not use funnel plots to assess small-study effects in the present NMA of preclinical 
studies, but it is worth noting that most studies had a small sample size.

\section{Conclusion}

In summary, this systematic review and NMA suggests that in preclinical studies of periodontal defect animal models, PDLSCs and BMSCs have consistently exhibited therapeutic benefits based on quantitative histologic data of NB, NC, and NPDL. PDLSCs have a favorable effect on NB and NPDL compared to GMSCs. Moreover, when compared with cell carrier-only therapies, DPSCs are superior for alveolar bone regeneration, while ADSCs are superior for cementum regeneration. Notably, future preclinical studies should employ robust experimental designs and reporting to overcome the limitations of current studies; such approaches include evaluating the biological rationality and accessibility of given stem cells, reporting adverse reactions, and using standardized models, blinding, and randomization, which may improve the successful translation of stem cell therapies in clinical practice.

\section{Supplementary information}

Supplementary information accompanies this paper at https://doi.org/10. 1186/s13287-020-01938-7.

Additional file 1. : Supplementary Table 1. Detailed search strategy.

Additional file 2. : Supplementary Table 2. The domain and corresponding questions in the SYRCLE's risk of bias tool.

Additional file 3. : Supplementary Table 3. References and the reasons for the exclusion in the full text reviewing stage.

Additional file 4. : Supplementary Table 4. Characteristics of included studies.

Additional file 5. : Supplementary Table 5. Summary of the characteristics of included studies.

Additional file 6. : Supplementary Fig. 1. Risk of bias of included preclinical studies. Review author's judgments about each risk of bias item for each included study. +, low risk; -, high risk;?, unclear risk.

Additional file 7. : Supplementary Fig. 2. Forest plots of pairwise metaanalyses showing the SMD and $95 \% \mathrm{Cl}$ of alveolar bone, cementum, and periodontal ligament regeneration for each included study. The graphs were generated using the 'mvmeta' suite in Stata. For all the plots, the solid vertical line ( 0 ) indicates no effect, SMDs of more than 0 favor stem cells on the right side of the $x$-axis. The size of the box indicates the weighting of each study, and the thin horizontal whisker indicates the 95\% Cl. The diamond represents overall effect size. Random-effects model was used to summarize the effect sizes. Heterogeneity is denoted by the $1^{2}$

Additional file 8. : Supplementary Table 6. Summary of the SUCRA, mean probabilities of being best and mean rank for each outcome.

Additional file 9. : Supplementary Table 7. The global and local inconsistency between direct and indirect sources of evidence.

Additional file 10. : Supplementary Fig. 3. Evaluation of inconsistency using loop-specific heterogeneity estimates. When at least three interventions are compared with each other in a network that forms a closed path, the loop-specific approach compares indirect evidence with direct evidence, and their differences define the inconsistency factor (IF). The magnitude of the IF, 95\% Cl of IF, and a loop-specific z-test can be used to infer the presence of inconsistency in each loop. IF close to zero indicates that direct evidence and indirect evidence are very consistent.

\section{Abbreviations}

ADSCs: Adipose tissue-derived stem cells; BMSCs: Bone marrow-derived stem cells; CCs: Cell carriers; Cl: Credible interval; DFSCs: Dental follicle-derived stem cells; DPSCs: Dental pulp-derived stem cells; ESCs: Embryonic stem cells; GMSCs: Gingival-derived stem cells; GTR: Guided tissue regeneration; IF: Inconsistency factor; iPSCs: Induced pluripotent stem cells; NB: Newly formed bone; NC: Newly formed cementum; NPDL: Newly formed periodontal ligament; PDL: Periodontal ligament; PDLSCs: Periodontal ligament stem cells; PICOS: Participants, interventions, comparisons, outcomes, and study; PTR: Periodontal tissue regeneration; RCT: Randomized controlled trials; SD: Standard deviation; SMD: Standardized mean difference; SUCRA: Surface under the cumulative ranking curve; SYRCLE: Systematic Review Centre for Laboratory Animal Experimentation; UMSCs: Umbilical cord mesenchymal stem cells

\section{Acknowledgments}

We acknowledge the kind support of Prof. Hao Chen from Nanjing University of Traditional Chinese Medicine for methodological assistance.

\section{Authors' contributions}

$Q L, G Y, J L, M D, N Z, H D$, and YM conceived and designed the study. QL, GY, and $H D$ selected the articles and extracted the data. QL, GY, JL, HD, and YM analyzed the data. QL, MD, NZ, and YM interpreted the data. QL wrote the first draft of the manuscript. All authors read and agree with the results and conclusions of this article.

\section{Funding}

This study was funded by the National Natural Sciences Foundation of China (No. 81571800), Jiangsu Provincial Medical Talent (No. ZDRCC2016016), Development of Science and Technology of Nanjing (No. 201803036), and Nanjing Medical Science and Technique Development Foundation (YKK19094)

\section{Availability of data and materials}

All data generated or analyzed during this study are included in this published article and its supplementary information files.

Ethics approval and consent to participate

Not applicable.

\section{Consent for publication}

Not applicable.

\section{Competing interests}

The authors declare that they have no competing interests.

\section{Author details}

${ }^{1}$ Department of Oral Implantology, Nanjing Stomatological Hospital, Medical School of Nanjing University, Nanjing, China. ${ }^{2}$ Central Laboratory, Nanjing Stomatological Hospital, Medical School of Nanjing University, Nanjing, China. ${ }^{3}$ Department of Orthodontics, Nanjing Stomatological Hospital, Medical School of Nanjing University, Nanjing, China.

Received: 17 June 2020 Accepted: 16 September 2020

Published online: 02 October 2020

\section{References}

1. Kinane DF, Stathopoulou PG, Papapanou PN. Periodontal diseases. Nat Rev Dis Primers. 2017;3:17038.

2. Kassebaum NJ, Smith AGC, Bernabé E, Fleming TD, Reynolds AE, Vos T, et al. Global, regional, and national prevalence, incidence, and disability-adjusted life years for oral conditions for 195 countries, 1990-2015: a systematic analysis for the global burden of diseases, injuries, and risk factors. J Dent Res. 2017:96(4):380-7.

3. Xu XY, Li X, Wang J, He XT, Sun HH, Chen FM. Concise review: periodontal tissue regeneration using stem cells: strategies and translational considerations. Stem Cells Transl Med. 2019:8(4):392-403.

4. Karring T, Nyman S, Gottlow J, Laurell L. Development of the biological concept of guided tissue regeneration--animal and human studies. Periodontol. 1993;1:26-35. 
5. Graziani F, Karapetsa D, Alonso B, Herrera D. Nonsurgical and surgical treatment of periodontitis: how many options for one disease? Periodontol. 2017;75(1):152-88.

6. Chen FM, Sun HH, Lu H, Yu Q. Stem cell-delivery therapeutics for periodontal tissue regeneration. Biomaterials. 2012;33(27):6320-44.

7. Vaquette C, Pilipchuk SP, Bartold PM, Hutmacher DW, Giannobile WV, Ivanovski S. Tissue engineered constructs for periodontal regeneration: current status and future perspectives. Adv Healthc Mater. 2018;7(21):e1800457.

8. Kao RT, Nares S, Reynolds MA. Periodontal regeneration - intrabony defects: a systematic review from the AAP regeneration workshop. J Periodontol. 2015;86(2 Suppl):S77-104.

9. Trofin EA, Monsarrat $P$, Kémoun P. Cell therapy of periodontium: from animal to human? Front Physiol. 2013;4:325

10. Sanz AR, Carrión FS, Chaparro AP. Mesenchymal stem cells from the oral cavity and their potential value in tissue engineering. Periodontol. 2015; 67(1):251-67.

11. Sallum EA, Ribeiro FV, Ruiz KS, Sallum AW. Experimental and clinical studies on regenerative periodontal therapy. Periodontol. 2019;79(1):22-55.

12. Ouchi T, Nakagawa T. Mesenchymal stem cell-based tissue regeneration therapies for periodontitis. Regen Ther. 2020;14:72-8.

13. Nuñez J, Vignoletti F, Caffesse RG, Sanz M. Cellular therapy in periodontal regeneration. Periodontol. 2019;79(1):107-16.

14. Wu PH, Chung HY, Wang JH, Shih JC, Kuo MYP, Chang PC, et al. Amniotic membrane and adipose-derived stem cell co-culture system enhances bone regeneration in a rat periodontal defect model. J Formos Med Assoc. 2016; 115(3):186-94

15. Mohammed E, Khalil E, Sabry D. Effect of adipose-derived stem cells and their exo as adjunctive therapy to nonsurgical periodontal treatment: a histologic and histomorphometric study in rats. Biomolecules. 2018;8(4):167.

16. Du J, Shan Z, Ma P, Wang S, Fan Z. Allogeneic bone marrow mesenchymal stem cell transplantation for periodontal regeneration. J Dent Res. 2014; 93(2):183-8.

17. Cai X, Yang F, Yan X, Yang W, Yu N, Oortgiesen DAW, et al. Influence of bone marrow-derived mesenchymal stem cells pre-implantation differentiation approach on periodontal regeneration in vivo. J Clin Periodontol. 2015;42(4):380-9.

18. Paknejad M, Eslaminejad MB, Ghaedi B, Rokn A-R, Khorsand A, EtemadMoghadam S, et al. Isolation and assessment of mesenchymal stem cells derived from bone marrow: histologic and histomorphometric study in a canine periodontal defect. J Oral Implantol. 2015:41(3):284-91.

19. Ma L, Hu J, Cao Y, Xie Y, Wang H, Fan Z, et al. Maintained properties of aged dental pulp stem cells for superior periodontal tissue regeneration. Aging Dis. 2019;10(4):793-806.

20. Khorsand A, Eslaminejad MB, Arabsolghar M, Paknejad M, Ghaedi B, Rokn AR, et al. Autologous dental pulp stem cells in regeneration of defect created in canine periodontal tissue. J Oral Implantol. 2013:39(4):433-43.

21. Hu J, Cao Y, Xie Y, Wang H, Fan Z, Wang J, et al. Periodontal regeneration in swine after cell injection and cell sheet transplantation of human dental pulp stem cells following good manufacturing practice. Stem Cell Res Ther. 2016;7(1):130.

22. Yu X, Ge S, Chen S, Xu Q, Zhang J, Guo H, et al. Human gingiva-derived mesenchymal stromal cells contribute to periodontal regeneration in beagle dogs. Cells Tissues Organs. 2013;198(6):428-37.

23. Liu Y, Zheng Y, Ding G, Fang D, Zhang C, Bartold PM, et al. Periodontal ligament stem cell-mediated treatment for periodontitis in miniature swine. Stem Cells. 2008;26(4):1065-73.

24. Ding G, Liu Y, Wang W, Wei F, Liu D, Fan Z, et al. Allogeneic periodontal ligament stem cell therapy for periodontitis in swine. Stem cells (Dayton). 2010;28(10):1829-38.

25. Mrozik KM, Wada N, Marino V, Richter W, Shi S, Wheeler DL, et al. Regeneration of periodontal tissues using allogeneic periodontal ligament stem cells in an ovine model. Regen Med. 2013:8(6):711-23.

26. Iwasaki K, Nagata M, Akazawa K, Watabe T, Morita I. Changes in characteristics of periodontal ligament stem cells in spheroid culture. J Periodontal Res. 2019;54(4):364-73.

27. Huang GT, Gronthos S, Shi S. Mesenchymal stem cells derived from dental tissues vs. those from other sources: their biology and role in regenerative medicine. J Dent Res. 2009;88(9):792-806.

28. Chen FM, Jin Y. Periodontal tissue engineering and regeneration: current approaches and expanding opportunities. Tissue Eng Part B Rev. 2010;16(2): 219-55.
29. Sandercock P, Roberts I. Systematic reviews of animal experiments. Lancet 2002;360(9333):586.

30. Bright R, Hynes K, Gronthos S, Bartold PM. Periodontal ligament-derived cells for periodontal regeneration in animal models: a systematic review. Periodontal Res. 2015;50(2):160-72.

31. Tassi SA, Sergio NZ, Misawa MYO, Villar CC. Efficacy of stem cells on periodontal regeneration: systematic review of pre-clinical studies. $J$ Periodontal Res. 2017;52(5):793-812.

32. Crossman J, Elyasi M, El-Bialy T, Flores MC. Cementum regeneration using stem cells in the dog model: a systematic review. Arch Oral Biol. 2018;91: $78-90$.

33. Amghar-Maach S, Gay-Escoda C, Sánchez-Garcés MÁ. Regeneration of periodontal bone defects with dental pulp stem cells grafting: systematic review. J Clin Exp Dent. 2019;11(4):e373-e81.

34. Dziedzic DSM, Mogharbel BF, Ferreira PE, Irioda AC, de Carvalho KAT. Transplantation of adipose-derived cells for periodontal regeneration: a systematic review. Curr Stem Cell Res Ther. 2019:14(6):504-18.

35. Portron S, Soueidan A, Marsden A-C, Rakic M, Verner C, Weiss P, et al. Periodontal regenerative medicine using mesenchymal stem cells and biomaterials: a systematic review of pre-clinical studies. Dent Mater J. 2019; 38(6):867-83.

36. Monsarrat $P$, Vergnes JN, Nabet $C$, Sixou M, Snead ML, Planat-Bénard $V$, et al. Concise review: mesenchymal stromal cells used for periodontal regeneration: a systematic review. Stem Cells Transl Med. 2014;3(6):768-74

37. Yan XZ, Yang F, Jansen JA, De Vries RBM, Van Den Beucken JJJP. Cell-based approaches in periodontal regeneration: a systematic review and metaanalysis of periodontal defect models in animal experimental work. Tissue Eng Part B Rev. 2015;21(5):411-26.

38. Gaubys A, Papeckys V, Pranskunas M. Use of autologous stem cells for the regeneration of periodontal defects in animal studies: a systematic review and meta-analysis. J Oral Maxillofac Res. 2018;9(2):e3-e.

39. Hutton B, Salanti G, Caldwell DM, Chaimani A, Schmid CH, Cameron C, et al. The PRISMA extension statement for reporting of systematic reviews incorporating network meta-analyses of health care interventions: checklist and explanations. Ann Intern Med. 2015:162(11):777-84.

40. Moher D, Liberati A, Tetzlaff J, Altman DG. Preferred reporting items for systematic reviews and meta-analyses: the PRISMA statement. BMJ. 2009; 339:b2535.

41. Hozo SP, Djulbegovic B, Hozo I. Estimating the mean and variance from the median, range, and the size of a sample. BMC Med Res Methodol. 2005;5:13.

42. Hooijmans CR, Rovers MM, de Vries RBM, Leenaars M, Ritskes-Hoitinga M, Langendam MW. SYRCLE's risk of bias tool for animal studies. BMC Med Res Methodol. 2014;14:43.

43. Deeks JJ, Higgins J, Altman DG, Green S. Cochrane handbook for systematic reviews of interventions version 5.1. 0 (updated March 2011). Cochrane Collaboration. 2011:276-81.

44. Salanti G. Indirect and mixed-treatment comparison, network, or multipletreatments meta-analysis: many names, many benefits, many concerns for the next generation evidence synthesis tool. Res Synth Methods. 2012;3(2): 80-97.

45. White IR, Barrett JK, Jackson D, Higgins JP. Consistency and inconsistency in network meta-analysis: model estimation using multivariate metaregression. Res Synth Methods. 2012;3(2):111-25.

46. White IR. Network meta-analysis. Stata J. 2015;15(4):951-85.

47. Salanti G, Ades AE, loannidis JP. Graphical methods and numerical summaries for presenting results from multiple-treatment meta-analysis: an overview and tutorial. J Clin Epidemiol. 2011;64(2):163-71.

48. Higgins JP, Jackson D, Barrett JK, Lu G, Ades AE, White IR. Consistency and inconsistency in network meta-analysis: concepts and models for multi-arm studies. Res Synth Methods. 2012;3(2):98-110.

49. Dias S, Welton NJ, Caldwell DM, Ades AE. Checking consistency in mixed treatment comparison meta-analysis. Stat Med. 2010;29(7-8):932-44.

50. Bucher HC, Guyatt GH, Griffith LE, Walter SD. The results of direct and indirect treatment comparisons in meta-analysis of randomized controlled trials. J Clin Epidemiol. 1997:50(6):683-91.

51. Akita D, Kano K, Saito-Tamura Y, Mashimo T, Sato-Shionome M, Tsurumachi N, et al. Use of rat mature adipocyte-derived dedifferentiated fat cells as a cell source for periodontal tissue regeneration. Frontiers in Physiology. 2016;7:50.

52. Akita D, Morokuma M, Saito $Y$, Yamanaka K, Akiyama $Y$, Sato M, et al. Periodontal tissue regeneration by transplantation of rat adipose-derived 
stromal cells in combination with PLGA-based solid scaffolds. Biomed Res. 2014:35(2):91-103.

53. Akizuki T, Oda S, Komaki M, Tsuchioka H, Kawakatsu N, Kikuchi A, et al. Application of periodontal ligament cell sheet for periodontal regeneration: a pilot study in beagle dogs. J Periodontal Res. 2005;40(3):245-51.

54. Babo PS, Cai X, Plachokova AS, Reis RL, Jansen JA, Gomes ME, et al. The role of a platelet lysate-based compartmentalized system as a carrier of cells and platelet-origin cytokines for periodontal tissue regeneration. Tissue Eng Part A. 2016;22(19-20):1164-75.

55. Cao Y, Liu Z, Xie Y, Hu J, Wang H, Fan Z, et al. Adenovirus-mediated transfer of hepatocyte growth factor gene to human dental pulp stem cells under good manufacturing practice improves their potential for periodontal regeneration in swine. Stem Cell Res Ther. 2015;6:249.

56. Dan $\mathrm{H}$, Vaquette $\mathrm{C}$, Fisher AG, Hamlet $\mathrm{SM}$, Xiao $\mathrm{Y}$, Hutmacher DW, et al. The influence of cellular source on periodontal regeneration using calcium phosphate coated polycaprolactone scaffold supported cell sheets. Biomaterials. 2014;35(1):113-22

57. Dogan A, Ozdemir A, Kubar A, Oygür T. Assessment of periodontal healing by seeding of fibroblast-like cells derived from regenerated periodontal ligament in artificial furcation defects in a dog: a pilot study. Tissue Eng. 2002;8(2):273-82.

58. Doğan A, Özdemir A, Kubar A, Oygür T. Healing of artificial fenestration defects by seeding of fibroblast-like cells derived from regenerated periodontal ligament in a dog: a preliminary study. Tissue Eng. 2003;9(6): 1189-96.

59. Duan $X$, Lin Z, Lin X, Wang Z, Wu Y, Ji M, et al. Study of platelet-rich fibrin combined with rat periodontal ligament stem cells in periodontal tissue regeneration. J Cell Mol Med. 2018;22(2):1047-55.

60. Fawzy El-Sayed KM, Mekhemar MK, Beck-Broichsitter BE, Bähr T, Hegab M, Receveur J, et al. Periodontal regeneration employing gingival marginderived stem/progenitor cells in conjunction with IL-1ra-hydrogel synthetic extracellular matrix. J Clin Periodontol. 2015;42(5):448-57.

61. Fu X, Jin L, Ma P, Fan Z, Wang S. Allogeneic stem cells from deciduous teeth in treatment for periodontitis in miniature swine. J Periodontol. 2014; 85(6):845-51.

62. Guo S, Kang J, Ji B, Guo W, Ding Y, Wu Y, et al. Periodontal-derived mesenchymal cell sheets promote periodontal regeneration in inflammatory microenvironment. Tissue Eng Part A. 2017;23(13-14):585-96.

63. Han J, Menicanin D, Marino V, Ge S, Mrozik K, Gronthos S, et al. Assessment of the regenerative potential of allogeneic periodontal ligament stem cells in a rodent periodontal defect model. J Periodontal Res. 2014;49(3):333-45.

64. Iwata T, Yamato M, Tsuchioka H, Takagi R, Mukobata S, Washio K, et al. Periodontal regeneration with multi-layered periodontal ligament-derived cell sheets in a canine model. Biomaterials. 2009;30(14):2716-23.

65. Jiang S, Tang K, Chen B, Yan F. Regenerative effect of hOPG gene-modified autologous PDLs in combination with cell transplantation on periodontal defection in beagle dogs. Cytotechnology. 2016;68(6):2613-23.

66. Lemaitre M, Monsarrat P, Blasco-Baque V, Loubiêres P, Burcelin R, Casteilla L, et al. Periodontal tissue regeneration using syngeneic adipose-derived stromal cells in a mouse model. Stem Cells Transl Med. 2017;6(2):656-65.

67. Li G, Han N, Zhang X, Yang H, Cao Y, Wang S, et al. Local injection of allogeneic stem cells from apical papilla enhanced periodontal tissue regeneration in minipig model of periodontitis. Biomed Res Int. 2018;2018:3960798.

68. Li H, Yan F, Lei L, Li Y, Xiao Y. Application of autologous cryopreserved bone marrow mesenchymal stem cells for periodontal regeneration in dogs. Cells Tissues Organs. 2009;190(2):94-101.

69. Li Y-F, Yan F-H, Zhong Q, Zhao X. Effect of hBMP-7 gene modified bone marrow stromal cells on periodontal tissue regeneration. Zhonghua Yi Xue Za Zhi. 2010;90(20):1427-30.

70. Liu D, Wang Y, Jia Z, Wang L, Wang J, Yang D, et al. Demethylation of IGFBP5 by histone demethylase KDM6B promotes mesenchymal stem cell-mediated periodontal tissue regeneration by enhancing osteogenic differentiation and anti-inflammation potentials. Stem Cells. 2015;33(8):2523-36.

71. Lu H, Wu Z-F, Tian Y. A study on the effects of cells and scaffolds tissue engineering on the periodontal regeneration. Zhonghua Kou Qiang Yi Xue Za Zhi. 2004;39(3):189-92.

72. Nagahara T, Yoshimatsu S, Shiba H, Kawaguchi H, Takeda K, Iwata T, et al. Introduction of a mixture of $\beta$-tricalcium phosphate into a complex of bone marrow mesenchymal stem cells and type I collagen can augment the volume of alveolar bone without impairing cementum regeneration. J Periodontol. 2015;86(3):456-64.
73. Nakahara T, Nakamura T, Kobayashi E, Kuremoto K-I, Matsuno T, Tabata $Y$, et al. In situ tissue engineering of periodontal tissues by seeding with periodontal ligament-derived cells. Tissue Eng. 2004; 10(3-4):537-44.

74. Nuñez J, Sanz-Blasco S, Vignoletti F, Muñoz F, Arzate H, Villalobos C, et al. Periodontal regeneration following implantation of cementum and periodontal ligament-derived cells. J Periodontal Res. 2012;47(1):33-44.

75. Ozasa M, Sawada K, Iwayama T, Yamamoto S, Morimoto C, Okura H, et al. Periodontal tissue regeneration by transplantation of adipose tissue-derived multi-lineage progenitor cells. Inflamm Regen. 2014;34(2):109-16.

76. Park J-Y, Jeon SH, Choung P-H. Efficacy of periodontal stem cell transplantation in the treatment of advanced periodontitis. Cell Transplant. 2011;20(2):271-85.

77. Rezaei M, Jamshidi S, Saffarpour A, Ashouri M, Rahbarghazi R, Rokn AR, et al. Transplantation of bone marrow-derived mesenchymal stem cells, plateletrich plasma, and fibrin glue for periodontal regeneration. Int J Periodontics Restorative Dent. 2019:39(1):e32-45.

78. Sano K, Usui M, Moritani Y, Nakazawa K, Hanatani T, Kondo H, et al. Cocultured spheroids of human periodontal ligament mesenchymal stem cells and vascular endothelial cells enhance periodontal tissue regeneration. Regen Ther. 2020;14:59-71.

79. Simsek SB, Keles GC, Baris S, Cetinkaya BO. Comparison of mesenchymal stem cells and autogenous cortical bone graft in the treatment of class II furcation defects in dogs. Clin Oral Investig. 2012;16(1):251-8.

80. Suaid FF, Ribeiro FV, Gomes TRLES, Silvério KG, Carvalho MD, Nociti FH Jr, et al. Autologous periodontal ligament cells in the treatment of Class III furcation defects: a study in dogs. J Clin Periodontol. 2012;39(4):377-84.

81. Suaid FF, Ribeiro FV, Rodrigues TL, Silvério KG, Carvalho MD, Nociti FH Jr, et al. Autologous periodontal ligament cells in the treatment of class II furcation defects: a study in dogs. J Clin Periodontol. 2011;38(5):491-8.

82. Takewaki M, Kajiya M, Takeda K, Sasaki S, Motoike S, Komatsu N, et al. MSC/ ECM cellular complexes induce periodontal tissue regeneration. J Dent Res. 2017:96(9):984-91.

83. Tcacencu I, Karlström E, Cedervall J, Wendel M. Transplanted human bone marrow mesenchymal stem cells seeded onto peptide hydrogel decrease alveolar bone loss. BioRes Open Access. 2012;1(5):215-21.

84. Tobita M, Uysal CA, Guo X, Hyakusoku H, Mizuno H. Periodontal tissue regeneration by combined implantation of adipose tissue-derived stem cells and platelet-rich plasma in a canine model. Cytotherapy. 2013;15(12): $1517-26$.

85. Tsumanuma Y, Iwata T, Kinoshita A, Washio K, Yoshida T, Yamada A, et al. Allogeneic transplantation of periodontal ligament-derived multipotent mesenchymal stromal cell sheets in canine critical-size supra-alveolar periodontal defect model. BioRes Open Access. 2016;5(1):22-36.

86. Tsumanuma Y, Iwata T, Washio K, Yoshida T, Yamada A, Takagi R, et al. Comparison of different tissue-derived stem cell sheets for periodontal regeneration in a canine 1-wall defect model. Biomaterials. 2011;32(25): 5819-25.

87. Vaquette C, Saifzadeh S, Farag A, Hutmacher DW, Ivanovski S. Periodontal tissue engineering with a multiphasic construct and cell sheets. J Dent Res. 2019;98(6):673-81

88. Wei F, Qu C, Song T, Ding G, Fan Z, Liu D, et al. Vitamin C treatment promotes mesenchymal stem cell sheet formation and tissue regeneration by elevating telomerase activity. J Cell Physiol. 2012;227(9):3216-24.

89. Weng $Y$, Wang $M$, Liu W, Hu X, Chai G, Yan Q, et al. Repair of experimental alveolar bone defects by tissue-engineered bone. Tissue Eng. 2006;12(6):1503-13.

90. Xu C, Xian X, Guo F. An experimental study on effect of astragalus polysaccharides on chitosan/polylactic acid scaffolds for repairing alveolar bone defects in dogs. Zhongguo Xiu Fu Chong Jian Wai Ke Za Zhi. 2007; 21(7):748-52.

91. Yan XZ, Van Den Beucken JJJP, Cai X, Yu N, Jansen JA, Yang F. Periodontal tissue regeneration using enzymatically solidified chitosan hydrogels with or without cell loading. Tissue Engineering - Part A. 2015;21(5-6):1066-76.

92. Yang Y, Rossi FMV, Putnins EE. Periodontal regeneration using engineered bone marrow mesenchymal stromal cells. Biomaterials. 2010;31(33):8574-82.

93. Yoo S-Y, Lee J-S, Cha J-K, Kim S-K, Kim C-S. Periodontal healing using a collagen matrix with periodontal ligament progenitor cells in a dehiscence defect model in beagle dogs. J Periodontal Implant Sci. 2019:49(4):215-27.

94. Yu N, Oortgiesen DAW, Bronckers ALJJ, Yang F, Walboomers XF, Jansen JA. Enhanced periodontal tissue regeneration by periodontal cell implantation. J Clin Periodontol. 2013;40(7):698-706. 
95. Yu X, Liu S, Wang W, Li S. Periodontal ligament-associated protein-1 delays rat periodontal bone defect repair by regulating osteogenic differentiation of bone marrow stromal cells and osteoclast activation. Int J Mol Med. 2018; 41(2):1110-8.

96. Yu Y, Bi CS, Wu RX, Yin Y, Zhang XY, Lan PH, et al. Effects of short-term inflammatory and/or hypoxic pretreatments on periodontal ligament stem cells: in vitro and in vivo studies. Cell Tissue Res. 2016;366(2):311-28.

97. Zang S, Jin L, Kang S, Hu X, Wang M, Wang J, et al. Periodontal wound healing by transplantation of jaw bone marrow-derived mesenchymal stem cells in chitosan/anorganic bovine bone carrier into one-wall infrabony defects in beagles. J Periodontol. 2016;87(8):971-81.

98. Zhan X, Yan FH, Xiao Y. Different densities of autologous bone marrow mesenchymal stem cell transplantation for repairing beagle canine teeth class II furcation defects. J Clin Rehabilitative Tissue Eng Res. 2008;12(16):3193-7.

99. Zhou W, Mei L. Effect of autologous bone marrow stromal cells transduced with osteoprotegerin on periodontal bone regeneration in canine periodontal window defects. Int J Periodontics Restorative Dent. 2012;32(5): e174-e81.

100. Aimetti M, Ferrarotti F, Gamba MN, Giraudi M, Romano F. Regenerative treatment of periodontal intrabony defects using autologous dental pulp stem cells: a 1-year follow-up case series. Int J Periodontics Restorative Dent. 2018;38(1):51-8.

101. Baba S, Yamada Y, Komuro A, Yotsui Y, Umeda M, Shimuzutani K, et al. Phase $1 /$ II trial of autologous bone marrow stem cell transplantation with a three-dimensional woven-fabric scaffold for periodontitis. Stem Cells Int. 2016;2016:6205910.

102. Chen FM, Gao LN, Tian BM, Zhang XY, Zhang YJ, Dong GY, et al. Treatment of periodontal intrabony defects using autologous periodontal ligament stem cells: a randomized clinical trial. Stem Cell Research and Therapy. 2016; 7(1):33.

103. Dhote $R$, Charde $P$, Bhongade $M$, Rao J. Stem cells cultured on beta tricalcium phosphate ( $\beta$-TCP) in combination with recombinant human platelet-derived growth factor - BB (rh-PDGF-BB) for the treatment of human infrabony defects. J Stem Cells. 2015;10(4):243-54.

104. Feng F, Akiyama K, Liu Y, Yamaza T, Wang TM, Chen JH, et al. Utility of PDL progenitors for in vivo tissue regeneration: a report of 3 cases. Oral Dis. 2010;16(1):20-8.

105. Ferrarotti F, Romano F, Gamba MN, Quirico A, Giraudi M, Audagna M, et al. Human intrabony defect regeneration with micrografts containing dental pulp stem cells: a randomized controlled clinical trial. J Clin Periodontol. 2018;45(7):841-50.

106. Iwata T, Yamato M, Washio K, Yoshida T, Tsumanuma Y, Yamada A, et al. Periodontal regeneration with autologous periodontal ligamentderived cell sheets - a safety and efficacy study in ten patients. Regen Ther. 2018;9:38-44.

107. Yamada Y, Ueda M, Hibi H, Baba S. A novel approach to periodontal tissue regeneration with mesenchymal stem cells and platelet-rich plasma using tissue engineering technology: a clinical case report. Int J Periodontics Restorative Dent. 2006;26(4):363-9.

108. Yan XZ, van den Beucken JJ, Both SK, Yang PS, Jansen JA, Yang F. Biomaterial strategies for stem cell maintenance during in vitro expansion. Tissue Eng Part B Rev. 2014;20(4):340-54.

109. Tomar GB, Srivastava RK, Gupta N, Barhanpurkar AP, Pote ST, Jhaveri $H M$, et al. Human gingiva-derived mesenchymal stem cells are superior to bone marrow-derived mesenchymal stem cells for cell therapy in regenerative medicine. Biochem Biophys Res Commun. 2010;393(3):37783.

110. Bartold PM, McCulloch CA, Narayanan AS, Pitaru S. Tissue engineering: a new paradigm for periodontal regeneration based on molecular and cell biology. Periodontol. 2000;24:253-69.

111. Duan X, Tu Q, Zhang J, Ye J, Sommer C, Mostoslavsky G, et al. Application of induced pluripotent stem (iPS) cells in periodontal tissue regeneration. J Cell Physiol. 2011;226(1):150-7.

112. Chien K-H, Chang Y-L, Wang M-L, Chuang J-H, Yang Y-C, Tai M-C, et al. Promoting induced pluripotent stem cell-driven biomineralization and periodontal regeneration in rats with maxillary-molar defects using injectable BMP-6 hydrogel. Sci Rep. 2018;8(1):114.

113. Wada N, Wang B, Lin NH, Laslett AL, Gronthos S, Bartold PM. Induced pluripotent stem cell lines derived from human gingival fibroblasts and periodontal ligament fibroblasts. J Periodontal Res. 2011;46(4): 438-47.
114. Yan X, Qin H, Qu C, Tuan RS, Shi S, Huang GT. iPS cells reprogrammed from human mesenchymal-like stem/progenitor cells of dental tissue origin. Stem Cells Dev. 2010;19(4):469-80.

115. Sankaranarayanan S, Jetty N, Gadagi JS, Preethy S, Abraham SJK. Periodontal regeneration by autologous bone marrow mononuclear cells embedded in a novel thermo reversible gelation polymer. J Stem Cells. 2013;8(2):99-103.

116. Yang J-R, Hsu C-W, Liao S-C, Lin Y-T, Chen L-R, Yuan K. Transplantation of embryonic stem cells improves the regeneration of periodontal furcation defects in a porcine model. J Clin Periodontol. 2013;40(4):364-71.

117. Yang H, Li J, Hu Y, Sun J, Guo W, Li H, et al. Treated dentin matrix particles combined with dental follicle cell sheet stimulate periodontal regeneration. Dent Mater. 2019;35(9):1238-53.

118. Kantarci A, Hasturk H, Van Dyke TE. Animal models for periodontal regeneration and peri-implant responses. Periodontol. 2015;68(1):66-82.

119. Oz HS, Puleo DA. Animal models for periodontal disease. J Biomed Biotechnol. 2011;2011:754857.

120. Aerssens J, Boonen S, Lowet G, Dequeker J. Interspecies differences in bone composition, density, and quality: potential implications for in vivo bone research. Endocrinology. 1998;139(2):663-70.

121. Sanz M, Dahlin C, Apatzidou D, Artzi Z, Bozic D, Calciolari E, et al. Biomaterials and regenerative technologies used in bone regeneration in the craniomaxillofacial region: consensus report of group 2 of the 15th European Workshop on Periodontology on Bone Regeneration. J Clin Periodontol. 2019;46(Suppl 21):82-91.

122. Khademhosseini $A$, Langer R. A decade of progress in tissue engineering. Nat Protoc. 2016;11(10):1775-81.

123. Aguado BA, Grim JC, Rosales AM, Watson-Capps JJ, Anseth KS. Engineering precision biomaterials for personalized medicine. Sci Transl Med. 2018; 10(424):eaam8645

124. Wan ACA. Recapitulating cell-cell interactions for organoid construction are biomaterials dispensable? Trends Biotechnol. 2016;34(9):711-21.

125. Murphy WL, MCDevitt TC, Engler AJ. Materials as stem cell regulators. Nat Mater. 2014;13(6):547-57.

126. Wu H, Han S, Wu B, Du X, Sheng Z, Lin J, et al. Single-cell mass cytometry reveals in vivo immunological response to surgical biomaterials. Appl Mater Today. 2019;16:169-78.

127. Sadtler K, Estrellas K, Allen BW, Wolf MT, Fan H, Tam AJ, et al. Developing a pro-regenerative biomaterial scaffold microenvironment requires $T$ helper 2 cells. Science (New York). 2016;352(6283):366-70.

128. Zwetsloot PP, Van Der Naald M, Sena ES, Howells DW, IntHout J, De Groot JA, et al. Standardized mean differences cause funnel plot distortion in publication bias assessments. eLife. 2017;6:e24260.

\section{Publisher's Note}

Springer Nature remains neutral with regard to jurisdictional claims in published maps and institutional affiliations.

\section{Ready to submit your research? Choose BMC and benefit from:}

- fast, convenient online submission

- thorough peer review by experienced researchers in your field

- rapid publication on acceptance

- support for research data, including large and complex data types

- gold Open Access which fosters wider collaboration and increased citations

- maximum visibility for your research: over $100 \mathrm{M}$ website views per year

At BMC, research is always in progress.

Learn more biomedcentral.com/submissions 